\title{
Guided surgery treatment for edentulous patients
}

\author{
Tratamentul edentaţiei totale prin implantologie ghidată
}

\author{
Alexandru Burcea ${ }^{1}$, Laur lacob ${ }^{2}$, Ştefan Țigăeru Polihroniade ${ }^{3}$, Cornelia Bîcleşanu ${ }^{4}$, \\ Anamaria Florescu ${ }^{4}$ \\ ${ }^{1}$ Disciplina de Chirurgie şi Implantologie Orală, Facultatea de Medicină Dentară, \\ Universitatea „Titu Maiorescu“, Bucureşti \\ ${ }^{2}$ YTS-Dental View, Bucureşti \\ ${ }^{3}$ Şcoala doctorală, Disciplina Odontoterapie, Facultatea de Medicină Dentară, \\ Universitatea „Titu Maiorescu“, Bucureşti \\ ${ }^{4}$ Facultatea de Medicină Dentară, Universitatea „Titu Maiorescu“, Bucureşti
}

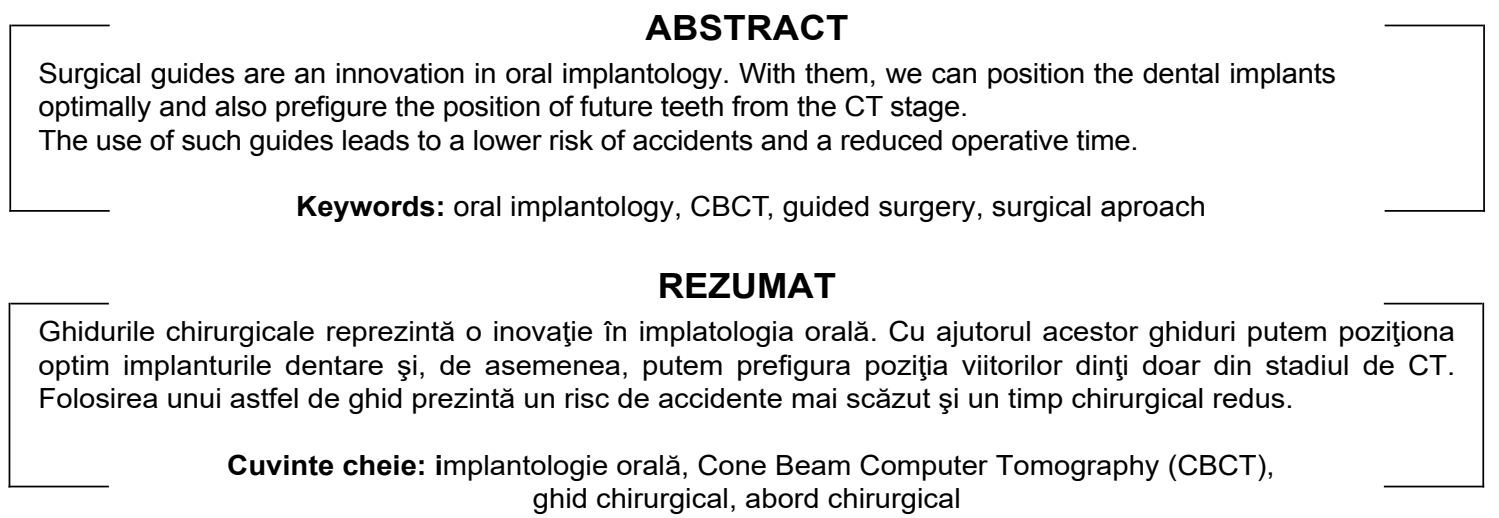

\section{INTRODUCERE}

Un diagnostic corect şi o precizie foarte mare a „planning-ului“" şi a etapei chirurgicale sunt absolut necesare pentru a creşte considerabil rata de succes şi pentru a respecta principiul ,primum non nocere“. Pentru a atinge aceste obiective, tehnologiile avansate de imagistică dentară, cum ar fi Cone Beam Computer Tomography (CBCT) sau scanarea intraorală, şi noile tehnologii în imprimarea 3D a ghidurilor chirurgicale devin practic indispensabile.

CBCT înseamnă tomografie computerizată cu fascicul conic. Această tehnologie a apărut în 2001 şi a însemnat un salt imens în imagistica medicală, îmbunătăţind atât diagnosticarea, cât şi planificarea tratamentului stomatologic, oferind maximum de informaţii cu o doză minimă de radiaţie. Este o investigaţie foarte simplă care nu necesită o pregătire specială în prealabil, se desfăşoară rapid, în câteva secunde, accesibilă ca preț şi uşor de utilizat.

Printre aplicaţiile folosirii CBCT-ului enumerăm:

1. Localizarea canalului mandibular şi trasarea nervului alveolar

2. Localizarea şi determinarea distanţei implantului faţă de structurile anatomice vitale

3. Stabilirea densităţii osoase în zona de interes

4. Evaluarea grosimii crestei alveolare şi vizualizarea conturului osos

5. Localizarea prechirurgicală precisă a zonei de inserare a implanturilor 
6. Alegerea optimă a dimensiunii şi a tipului de implant şi posibilitatea simulării de implant cu sisteme software specializate

7. Evaluarea exactă a volumului şi a raportului sinusurilor maxilare cu elementele anatomice învecinate

\section{SCANAREA INTRAORALĂ}

Este o metodă de înregistrare care foloseşte metoda triangulaţiei, cu ajutorul unui dispozitiv care face 3.000 de poze pe secundă şi reproduce 3D, într-un soft, forma dinţilor şi a maxilarelor la un maximum de acuratețe.

Folosirea scanării intraorale elimină dezavantajele materialelor de amprentă atât în procesul de amprentare, cât şi în cel de turnare a modelului. Restaurările create prin procesul digital au o potrivire mai precisă şi necesită mai puţine ajustări. Amprentele sunt uşor de luat şi nu este necesară repetarea lor. În situaţia amprentării clasice pentru restaurările pe implanturi, rezultatul poate fi destul de inexact, dar cu amprenta digitală nu există nicio şansă de distorsiune. Este corectă şi extrem de valoroasă. Oferă libertatea totală de a proiecta de la un zâmbet frumos nou la un design chirurgical complex al implantului cu restaurări finale, toate într-un singur proces.

Ghidurile chirurgicale sunt dispozitive utilizate pentru a ghida, pe toate axele, atât forajul, cât şi inserarea implantului. Ghidul chirurgical este confecţionat pentru fiecare pacient, pentru o adaptare optimă, indiferent dacă este susţinut de os, gingie sau dinţi.

Ghidurile sunt necesare pentru că, oricât de multe informaţii s-ar obţine printr-o analiză a CBCT, este foarte dificil de pus în practică ceea ce se vede digital cu ceea ce se doreşte să se obţină real, în cavitatea bucală.

Avantajele ghidului chirurgical sunt multiple, însă dintre cele mai importante enumerăm: transferul chirurgical al planingului digital, predictibilitate, siguranţa mai mare în timpul manoperii chirurgicale şi risc de accidente mai scăzut, folosirea la maximum a substratului osos existent. $\mathrm{Cu}$ ajutorul ghidurilor chirurgicale, avem instrumentele necesare pentru a obţine rezultate previzibile şi estetice pe baza planificării protetice. Deoarece ştim exact cum va fi poziţionat implantul în cavitatea bucală, putem avea din partea tehnicianului deja pregătite atât coroana pt încărcare imediată, cât şi bontul personalizat.

\section{ETAPELE REALIZĂRII GHIDULUI CHIRURGICAL}

\section{Efectuarea CBCT (partea ososă)}

2. Efectuarea scanării intraorale

3. Corelarea datelor obţinute din analiza CBCT cu cele din scanarea intraorală

4. Realizarea „planning-ului““ digital cu ajutorul softurilor de specialitate

5. Planificarea poziţiilor optime pentru implant. Se plasează virtual implanturile, ţinând cont de situaţia clinică, inclusiv de protezele existente, gingii, densitate osoasă şi poziţiile elementelor nervoase.

6. Proiectarea ghidului chirurgical. Se proiectează ghidul chirurgical personalizat, bazat pe poziţiile implantului şi scanarea suprafeţei.

7. Printarea ghidului chirurgical

\section{PREZENTARE DE CAZ}

Pacient în vârstă de 65 de ani, aparent clinic sănătos, edentat total atât maxilar, cât şi mandibular, se prezintă în cabinetul dentar pentru reabilitarea totală a cavităţii bucale (fig. 1-4).

După consultaţia în cabinetul stomatologic, pacientului i se stabilesc diagnosticul şi planul de tratament. Se optează pentru o reabilitare implantoprotetică pe 8 implanturi, cu ghid chirurgical, la maxilar, iar la mandibulă o reabilitare implantoprotetică pe 6 implanturi, fără ghid chirurgical.

Realizarea reabilitării totale a cavităţii bucale va fi compusă din 3 etape:

1. Implantare pentru ambele arcade

2. Protezarea provizorie cu proteze acrilice captuşite cu material moale

3. Realizarea lucrărilor protetice definitive înşurubate pentru ambele arcade după 4 luni.

Pregătirile pentru scanare se fac prin realizarea unui set de amprente ale maxilarelor edentate, pe baza cărora se vor realiza modelele de scanare (fig. 5). 


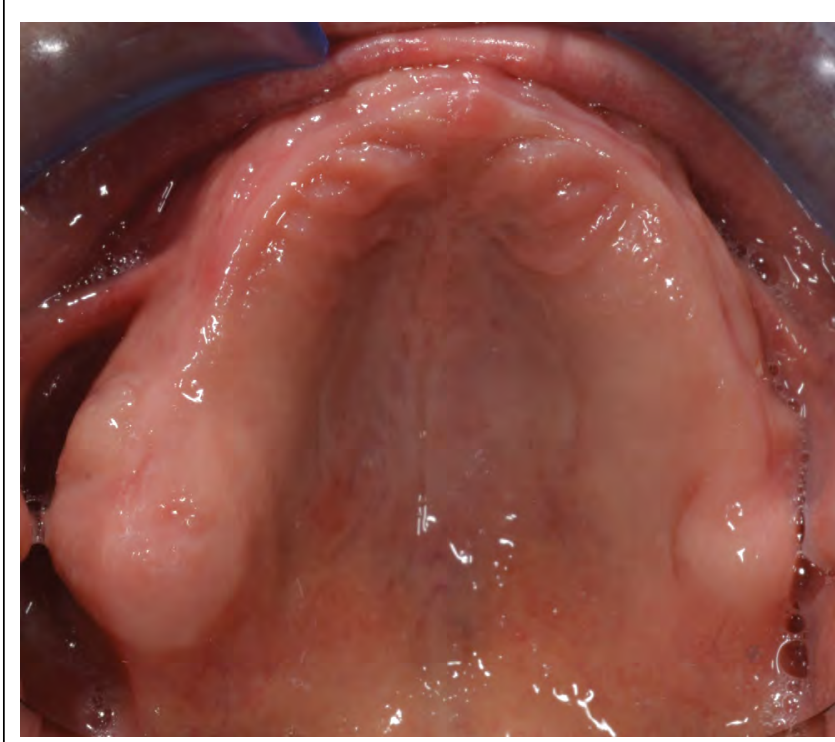

FIGURA 1. Situație inițială maxilar

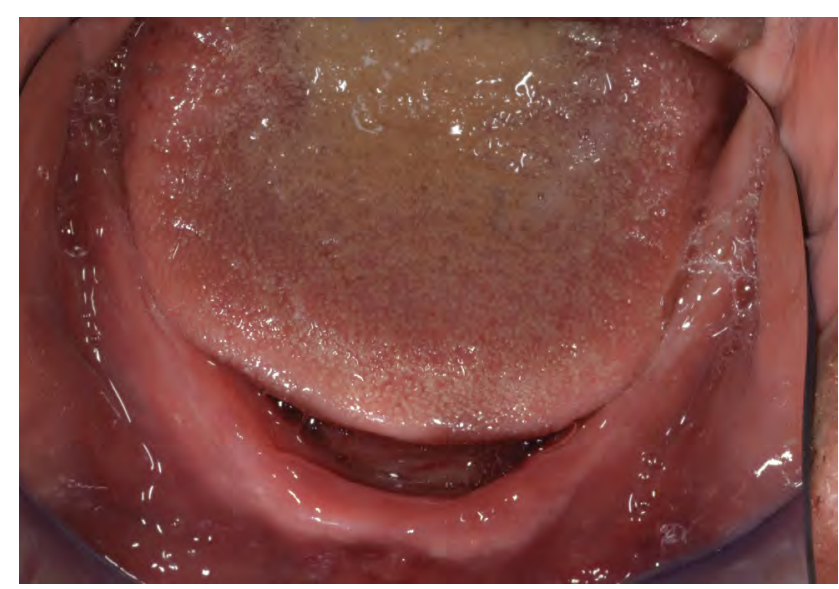

FIGURA 2. Situație inițială mandibulă

IYTS-Dental VieW

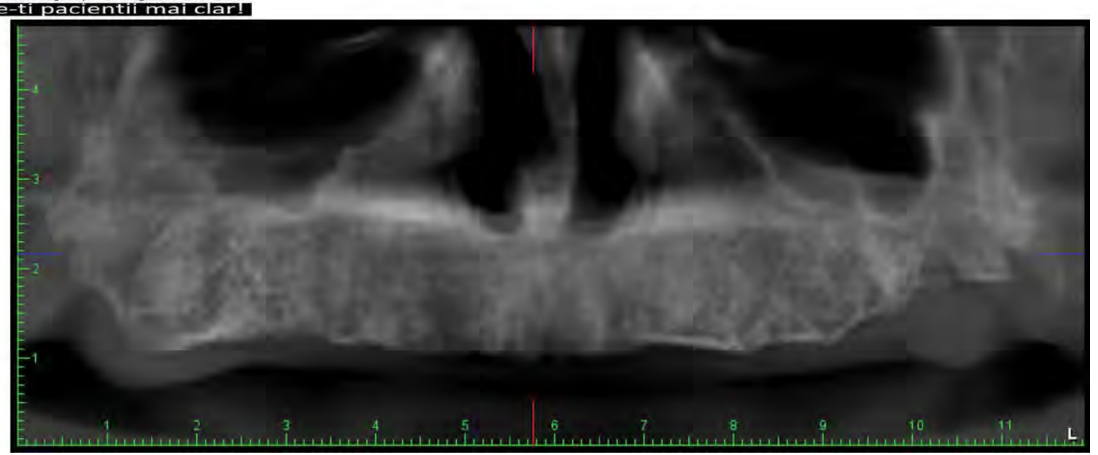

FIGURA 3. Rx inițial maxilar

IYTS-Dental View

Centre de Radiologie si Tomografie Dentară
privesste-ti paacientil mal man!

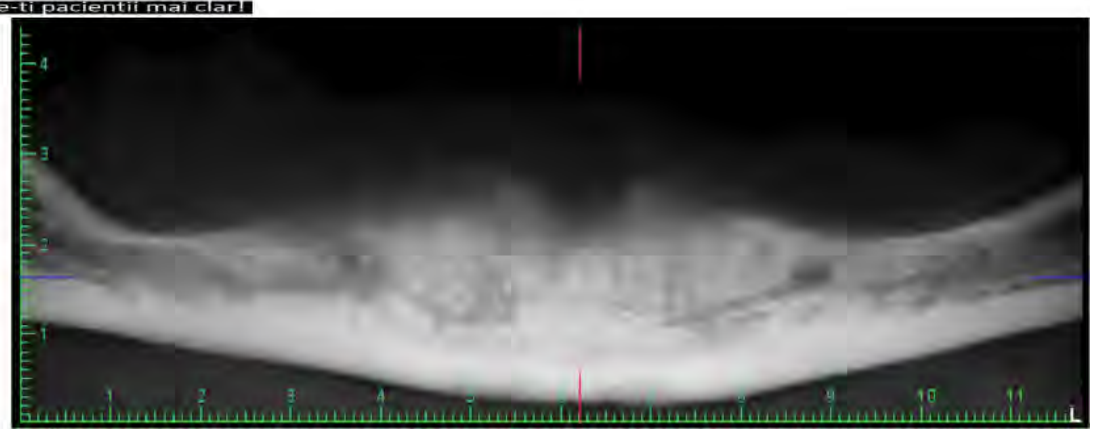

FIGURA 4. Rx inițial mandibulă

FIGURA 1-4. Aspect clinic, radiologic inițial, maxilar şi mandibular 


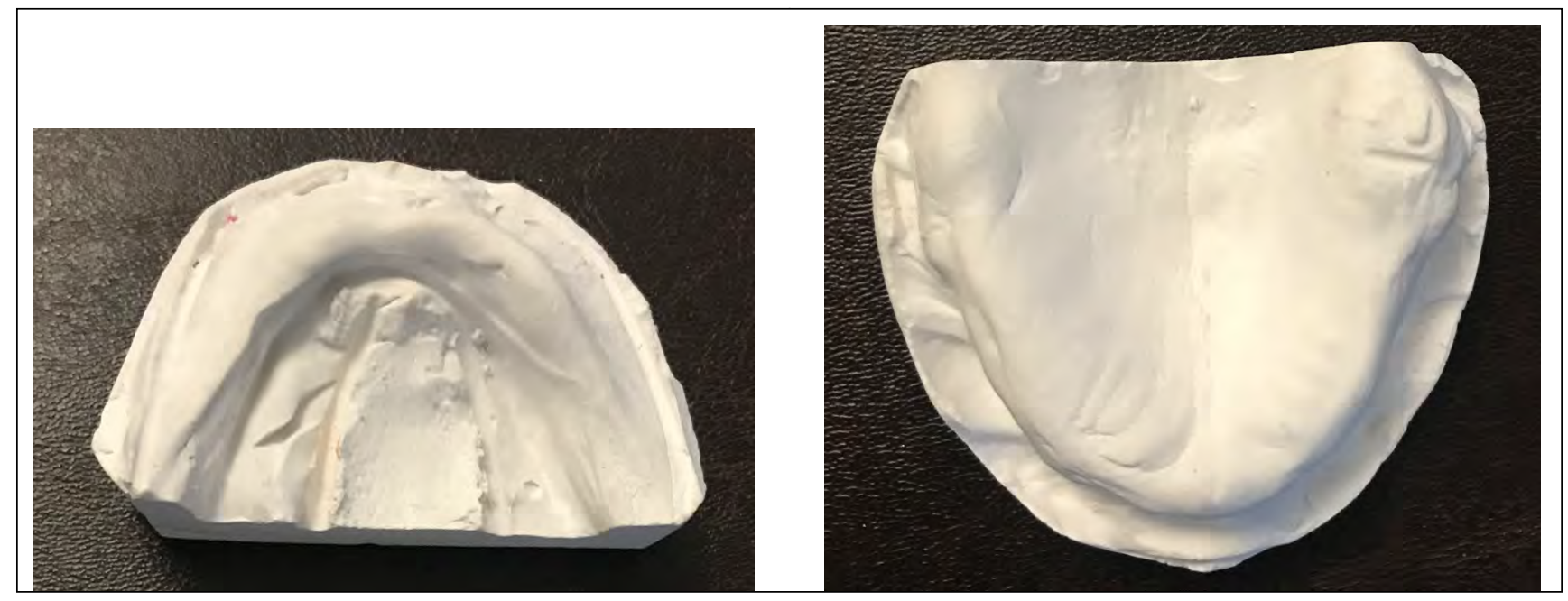

FIGURA 5. Model maxilar şi mandibular

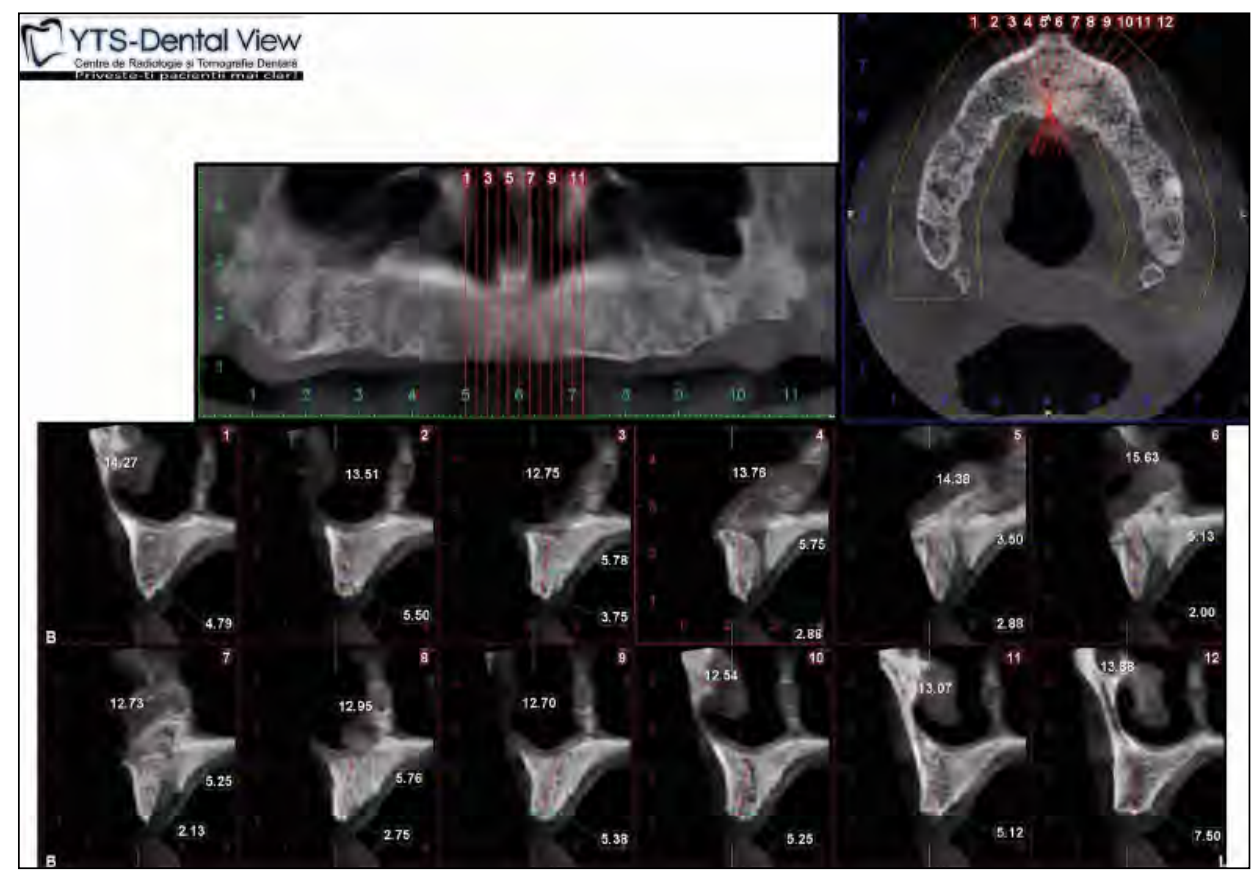

LYTS-Dental View

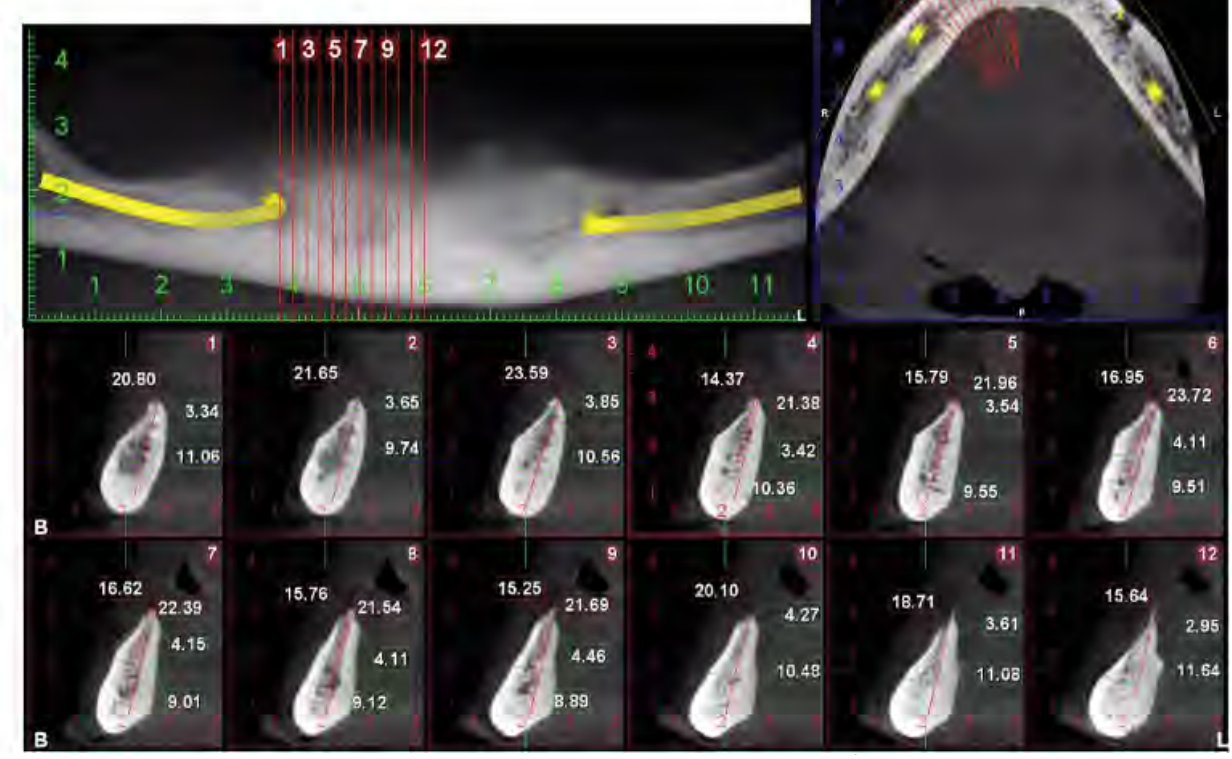

FIGURA 6. CBCT maxilar şi

mandibular 
Dupa scanarea modelelor, pacientului i se va efectua o tomografie dentară 3D (CBCT) în centrul de radiologie (fig. 6).

Urmează apoi planificarea in echipă, cu ajutorul programelor software de imagistică, al planului de chirurgie ghidată, în care vor fi prefigurate poziţiile ideale ale implanturilor şi ale viitoarelor lucrări dentare: forma dinţilor, mărimea lor, ocluzia (fig. 7).
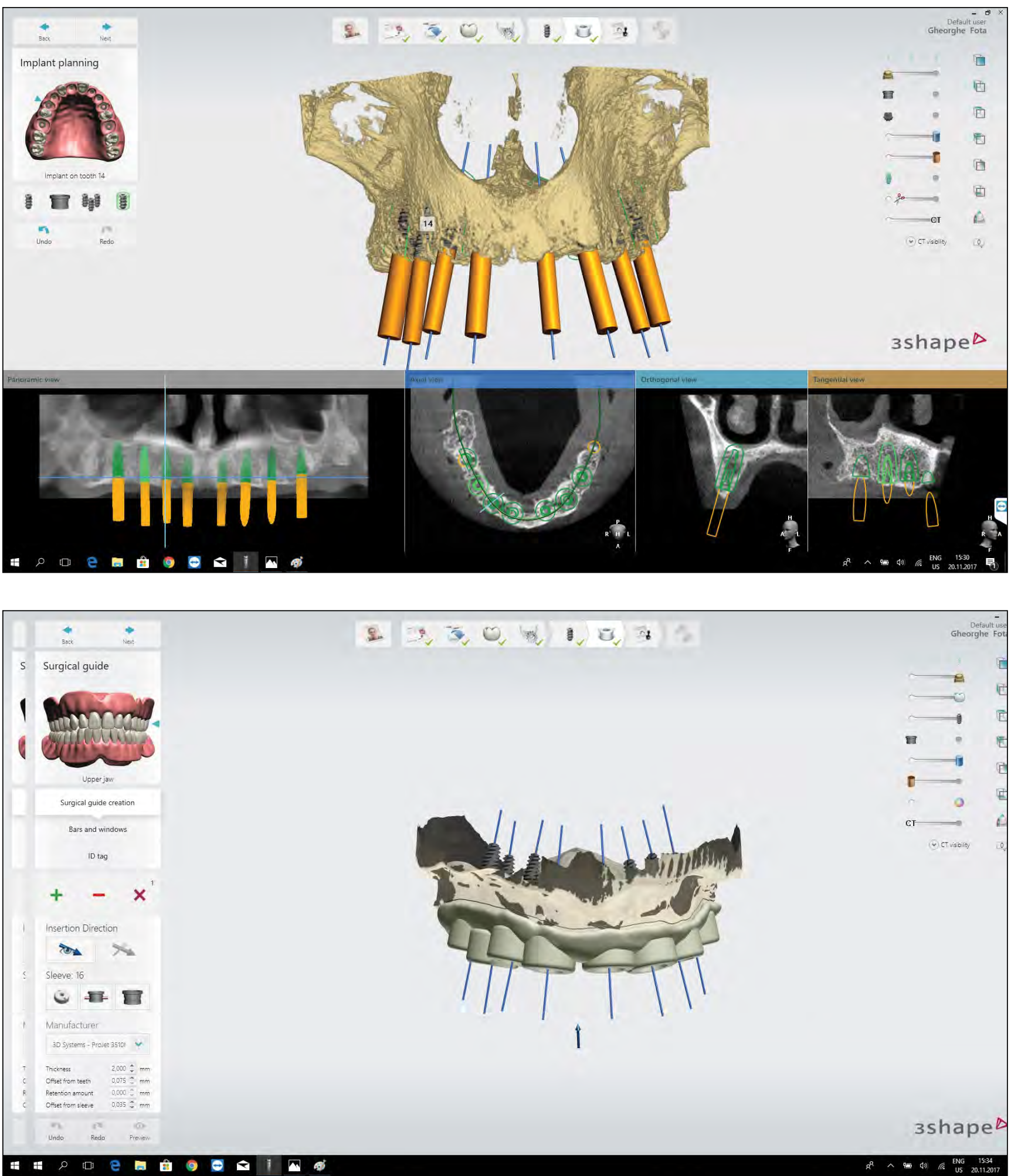

FIGURA 7. Planificarea cu ajutorul programelor software de imagistică 
$\mathrm{Cu}$ ajutorul ghidului chirurgical, întreaga intervenţie a fost realizată în mai puţin de 30 de minute (fig. 8).
Modelele cu şabloanele, bite index-ul, tomografia 3D şi planul terapeutic sunt trimise la firma producătoare pentru realizarea ghidurilor chirurgicale (fig. 9).
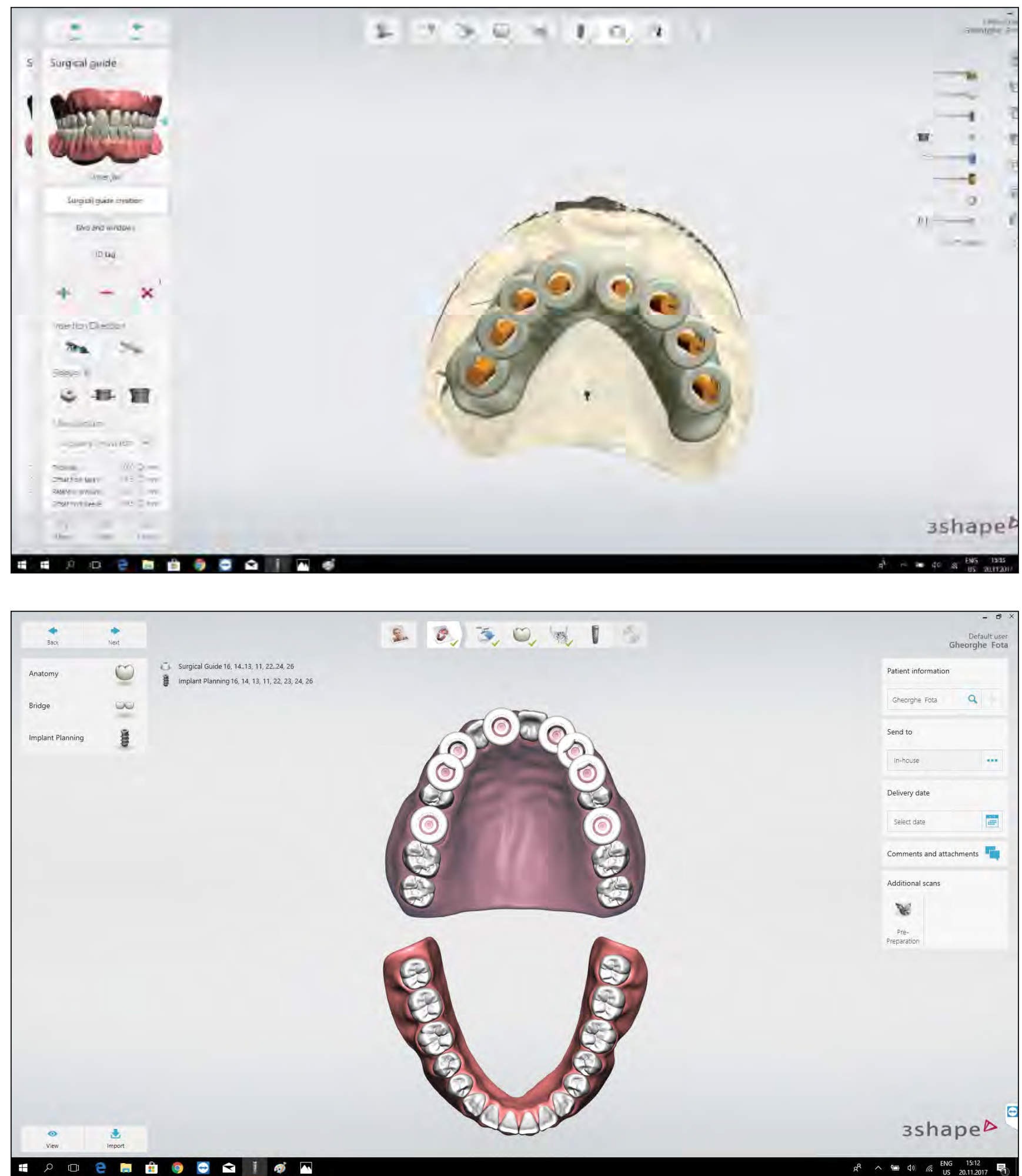

FIGURA 8. Ghidul chirurgical virtual finalizat 


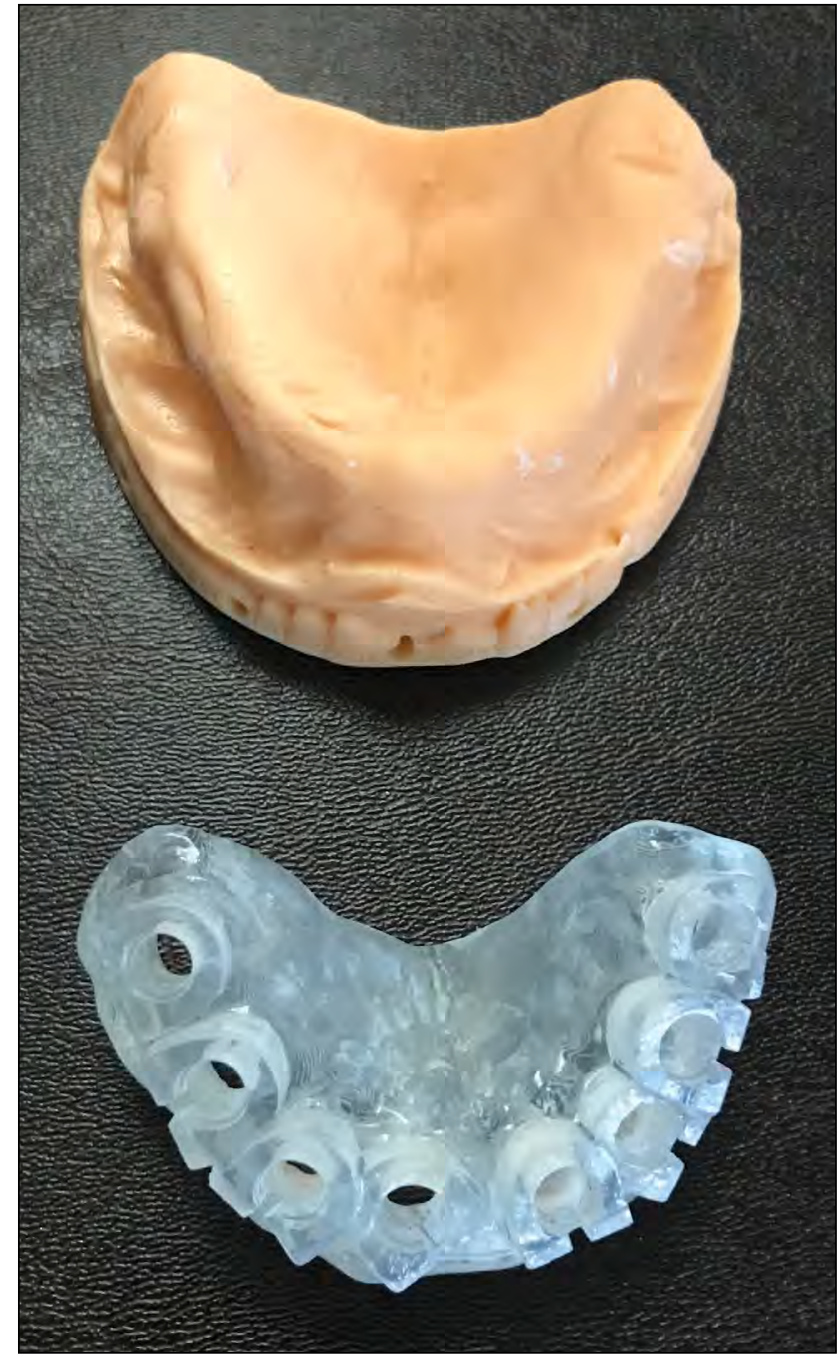

FIGURA 9. Ghidul chirurgical şi modelul maxilar printat

După fabricarea ghidului chirurgical şi trimiterea acestuia în cabinetul stomatologic, urmează etapa chirurgicală.

În urma efectuării anesteziei loco-regionale, chirurgul fixează ghidul în gura pacientului şi poziţionează implanturile doar în poziţia permisă de ghid, reducând la minimum erorile care ar putea să apară în cursul acestei intervenţii şi asigurând o vindecare rapidă şi un efect estetic maximal (fig. 10-19).

\section{DISCUȚII}

Pentru a evita zone anatomice vitale (artere, vene, nervi, sinus, cavitatea nazală, rădăcinile dinţilor), planificarea şi inserarea ghidată a implanturilor pot fi de mare ajutor. Posibilitatea de a vizualiza anatomia maxilarelor, în timpul planificării ghidurilor chirurgicale pentru a insera implantul conform cu poziţia dentară ideală, reprezintă un instrument puternic si predictibil.
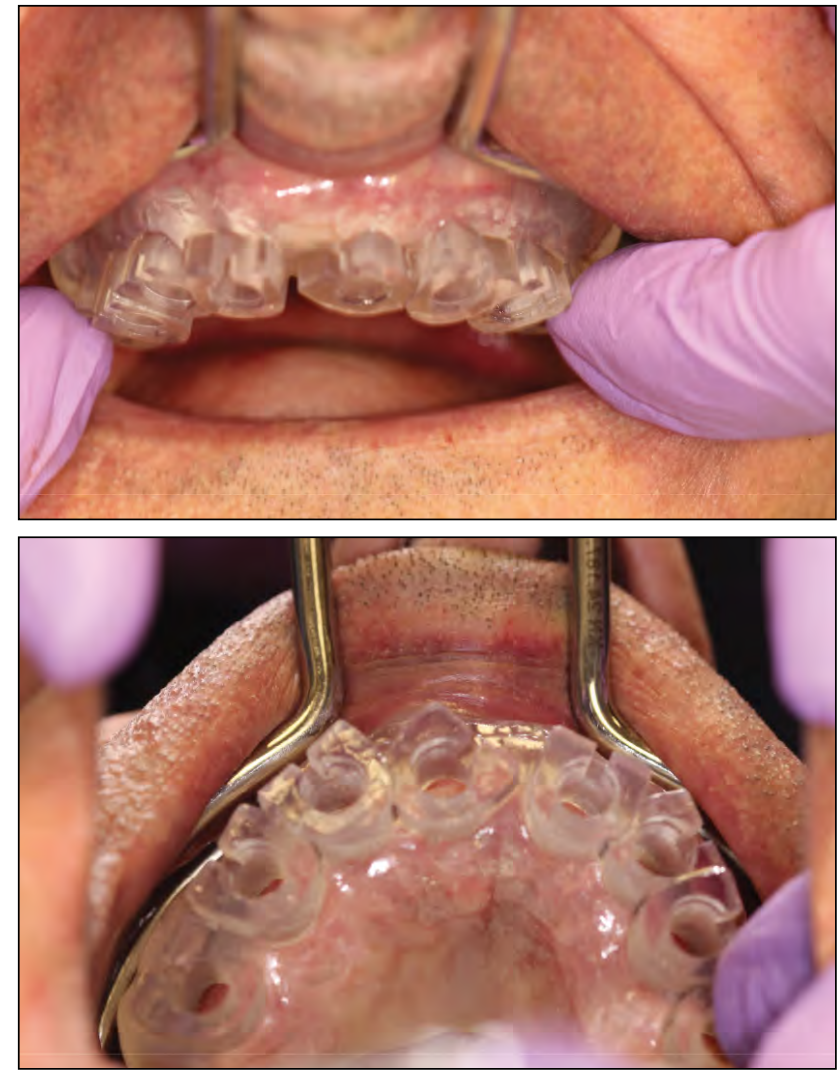

FIGURA 10. Poziționarea ghidului chirurgical în cavitatea orală

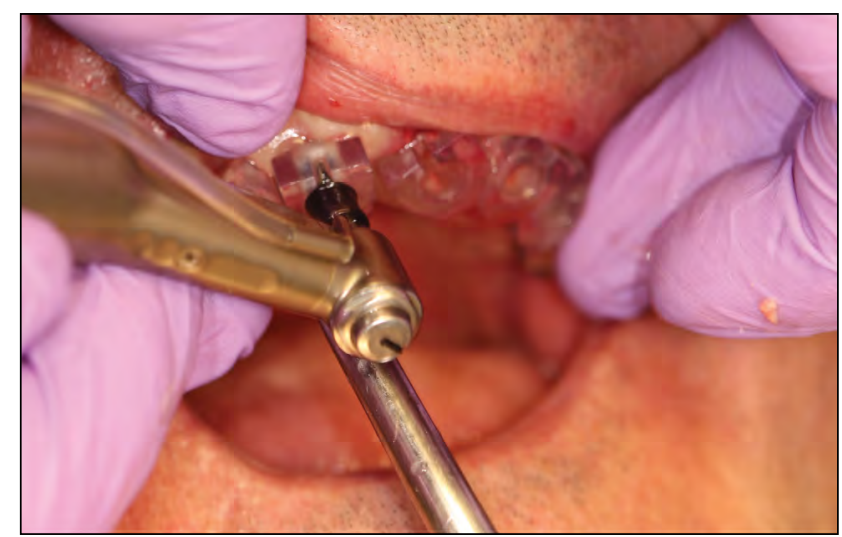

FIGURA 11. Frezajul prin ghidul chirurgical

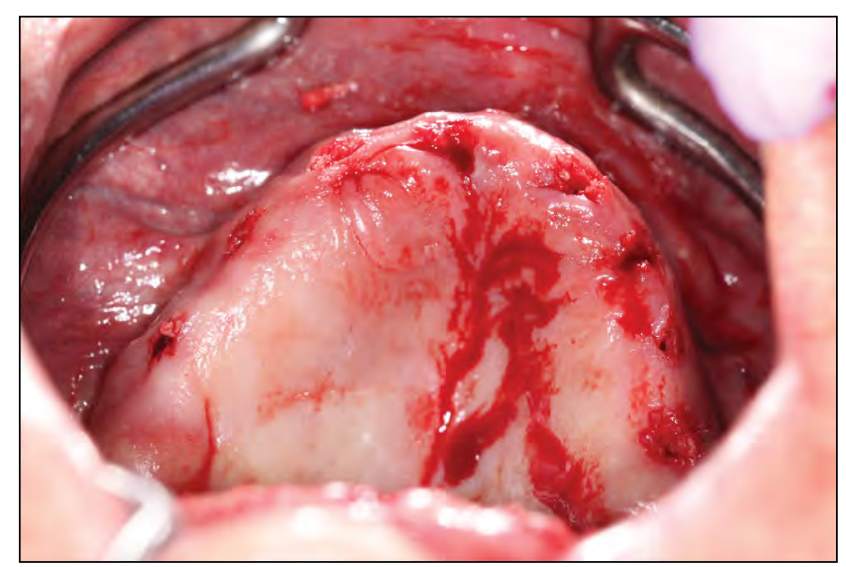

FIGURA 12. Osteotomiile transmucozale 


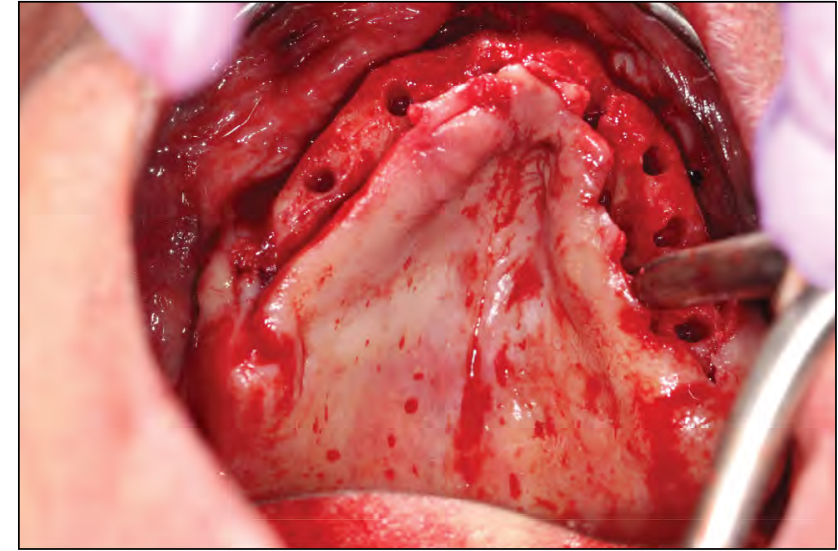

FIGURA 13. Osteotomiile preparate cu ultima freză din trusa caracteristică sistemului de implanturi

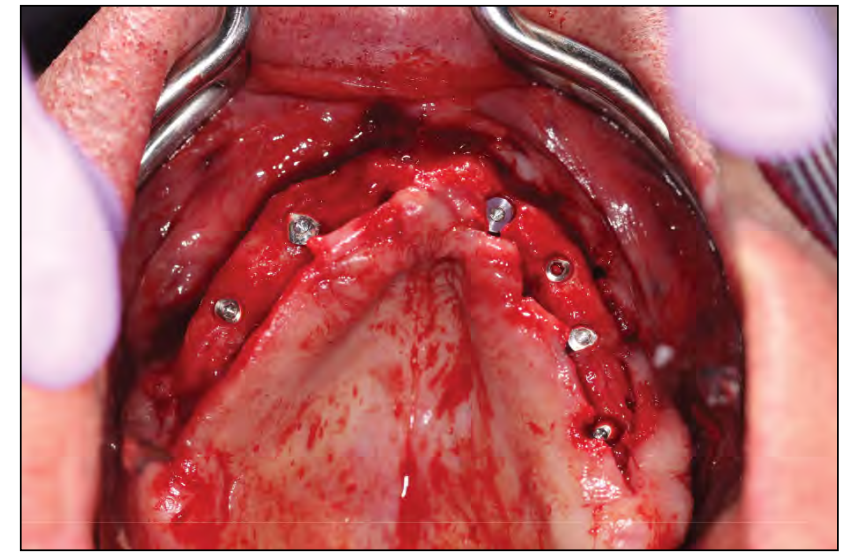

FIGURA 14. Implanturile inserate

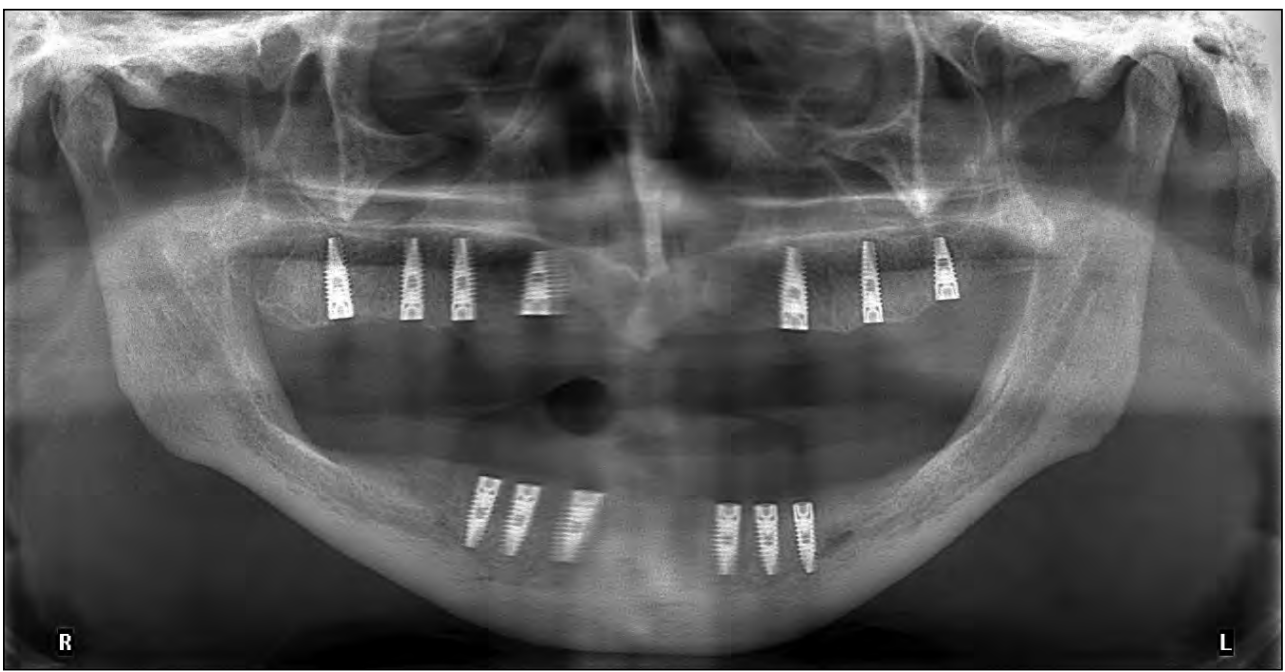

FIGURA 15. OPG postintervenție

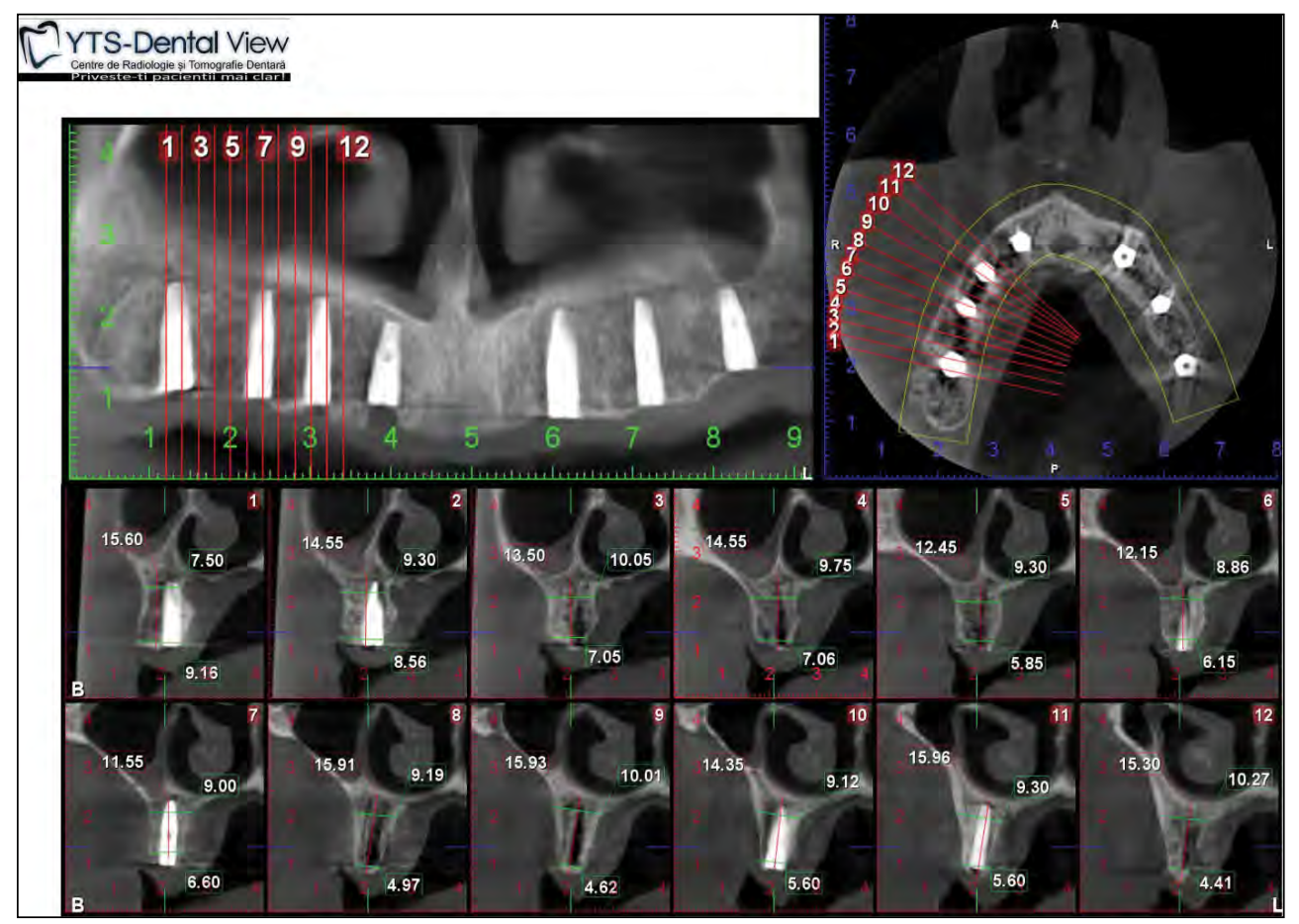




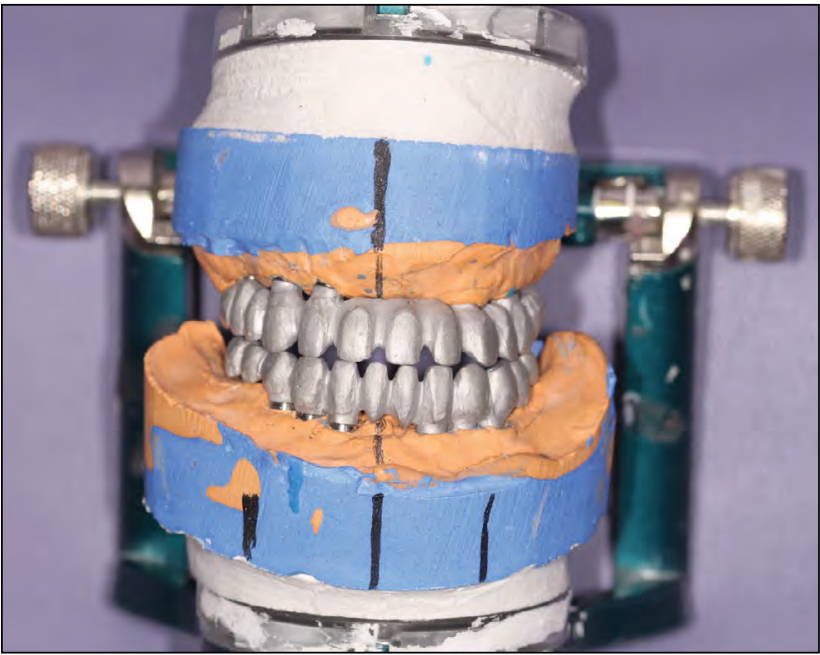

FIGURA 17. Verificarea componentelor metalice ale lucrărilor protetice

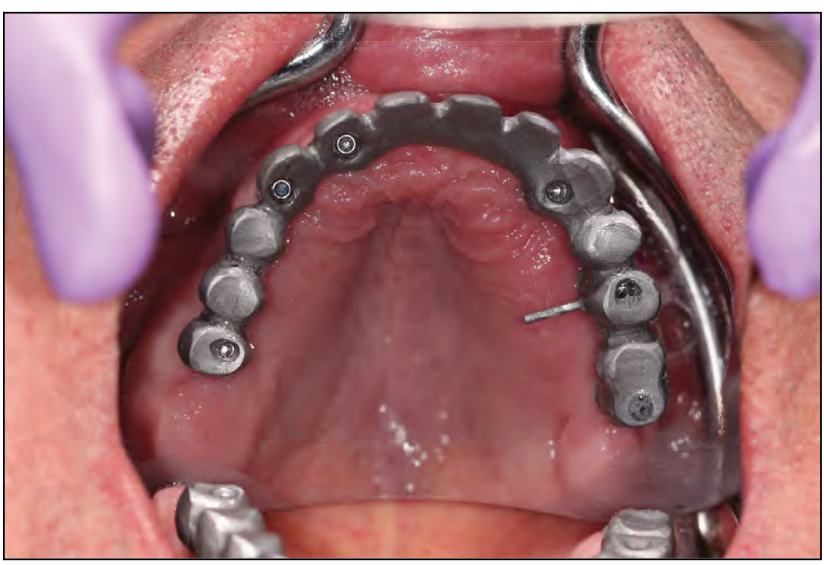

FIGURA 18. Verificarea intraorală a componentelor metalice ale lucrărilor protetice

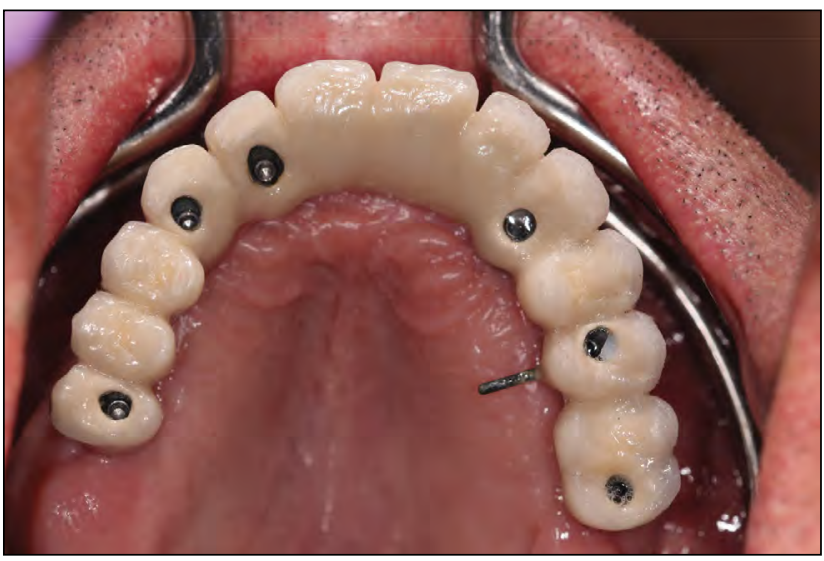

FIGURA 19. Lucrarea protetică maxilară înşurubată realizată din ceramică pe suport metalic
La pacienţii $\mathrm{cu}$ volum osos deficitar, edentaţii limitate ca spaţiu mezio-distal sau vestibulo-oral, cu traume sau patologii sau chiar în cazurile în care poziţia adecvată a implanturilor este esenţială pentru estetica restaurării protetice planificate, chirurgia ghidată va oferi beneficii importante atât pacientului, cât şi întregii echipe, rezultatele terapeutice fiind aproape de perfecţiune.

\section{CONCLUZII}

Prin combinarea software-ului de proiectare cu CBCT, scanare intraorală şi printarea unui ghid chirurgical, se asigură un diagnostic cuprinzător, planificarea tratamentului şi rezultate foarte previzibile.

\section{Mențiune}

Toţi autorii au contribuţie egală în realizarea acestui articol.

\section{BIBLIOGRAFIE}

1. HM Barbu, RM Comăneanu, A Burcea, C Hăineală, O Smătrea, DL Ghergic. Planificarea reabilitării orale într-un caz complex utilizând soft-ul SimPlant. Congresul Comun SRS-GAO cu participare internaţională, Bucureşti, 2011, cu rezumat publicat in Revista Română de Stomatologie, Vol. LVII, Nr. 2.

2. A Burcea. Regenerarea osoasă ghidată în implantologia orală. Ed. Printech, Bucureşti, 2014.

3. H Barbu, A Burcea, A Lorean, M Comăneanu, D Referendaru. Chirurgia implantara de la simplu la complex., Ed. Printech, Bucureşti, 2017. 